\title{
Phytochemical screening and antidiabetic potentiality of Pavetta indica L. (Angiosperms: Rubiaceae) methanol extract on streptozotocin induced diabetic mice
}

T. Venkatachalam», M. Chitra, P. Kalaiselvi, A. Chitra, K. Sumathi, C. M. Suresh Babu, N. Senthilkumar and K. Sattanathan* Department of Pharmaceutical Chemistry, JKKMMRF-Annai JKK Sampoorani Ammal College of Pharmacy, B. Komarapalaym, Namakkal-638 183, Tamil Nadu, India

*Department of Pharmaceutical Chemistry, Paavai College of Pharmacy and Research, Puduchatram-637408, Tamil Nadu, India

\section{Article Info}

Article history

Received 1 October 2021

Revised 16 November 2021

Accepted 17 November 2021

Published Online 30 December 2021

\section{Keywords}

Antidiabetic

Biochemical parameters

Glibenclamide,

Oral glucose tolerance test

Pavetta indica L.

Streptozotocin

\begin{abstract}
In the present study, the methanolic leaves extract of Pavetta indica L. (PI) was studied for antidiabetic activity in streptozotocin (STZ) induced diabetic mice. The dried leaves were powdered and extracted with methanol solvent by using Soxhlet method. Preliminary phytochemical investigation was carried out for determination of presence of bioactive constituents. Thereafter, the acute toxicity study was conducted for the selection of the dose and further the activity was studied as per OECD guideline. The antidiabetic activity was performed in STZ induced diabetic rats at the doses of 200 and $400 \mathrm{mg} / \mathrm{kg}$ body weight (b.w.) p.o. per day for 28 days. The fasting blood glucose levels (BGL), serum insulin level followed by biochemical parameters, viz., glycosylated hemoglobin, total cholesterol (TC), triglycerides (TG), high density lipoproteins (HDL) and low density lipoproteins (LDL) were evaluated and all the results were compared with standard glibenclamide (10 mg/kg b.w.). AST (aspartate aminotransferase), ALT (alanine aminotransferase), and ALP (alkaline phosphatase) levels were also estimated. The leaves methanol extract of PI (MEPI) showed the presence of alkaloids, carbohydrate, flavonoids, phenolic and tannins. Further, the results indicated significant increase in the body weight, liver glycogen, serum insulin and HDL levels and decrease in blood glucose, glycosylated hemoglobin, total cholesterol and serum triglycerides when compared with glibenclamide. MEPI at both the doses $(200$ and $400 \mathrm{mg} / \mathrm{kg})$ showed a significant decrease in glucose, AST, ALT, and ALP levels in diabetic mice and finally concluded that PI has potential antidiabetic activity in STZ induced diabetes.
\end{abstract}

\section{Introduction}

Diabetes mellitus (DM) is a chronic metabolic and an endocrine disorder which is very common to the people worldwide. This disorder is mainly characterized by insufficiency of insulin action and as a result, disruption in carbohydrates, protein, and fat metabolism (Seshiah, 2016). According to International Diabetes Federation (IDF, 2013), in worldwide, the same is expected to rise to 592 million by 2035 . It was estimated that about 65 million diabetic patients in India were affected in 2013 and it is expected to cross 109 million by 2030 (IDF, 2013). The mental tension, change in food pattern and especially diet intake and change in lifestyle in the fast daily life (Manickam and Periyasamy, 2013) are the main responsible for this life threatening disorder. There are many synthetic medicines available in market for the treatment of this disorder but either too costlier or have serious adverse effects like insulin resistance, hypersensitivity and metallic taste, hypoglycemic coma, etc. ( Nyunai et al., 2009). Therefore, in the recent years, natural plant based treatments gained tremendous success in

Corresponding author: Dr. T. Venkatachalam

Department of Pharmaceutical Chemistry, JKKMMRF-Annai JKK Sampoorani Ammal College of Pharmacy, B. Komarapalaym, Namakkal-638 183, Tamil Nadu, India

E-mail: venkatmohana301108@gmail.com

Tel.: +91-9843441716

Copyright (c) 2021 Ukaaz Publications. All rights reserved.

Email: ukaaz@yahoo.com; Website: www.ukaazpublications.com managing diabetic disorder in both developed and developing countries with the safe or very low adverse effects (Patil et al., 2013) with valuable therapeutic agents, both in modern and in traditional medicine. Therefore, all efforts of extensive research have been diverted in the new direction, i.e., tow ards herbal sources (Dubey et al., 2020). Ethnobotanical information indicates a vast number of medicinal plants show their hypoglycaemic or antidiabetic potentiality with their bioactive secondary metabolites (Lanjhiyana et al., 2011). India with its diverse climatic zones recognized as a hub of medicinal plants. Therefore, the search for safer and effective antidiabetic agents has become the current focus and with this concept, the present activity was selected.

Of late, Pavetta indica L. (PI) belongs to the family Rubiaceae, a shrub growing up to 3-5 meters of height. The opposite branches consist of membranous leaves with grey bark, smooth, irregularly scaly when mature greenish cream (Gupta et al., 2013). The leaves are simple, glabrous and variable in shape. The inflorescence is corymbose cyme, with white terminal flowers. The fruit is a berry with two pyrenes and seeds, one per pyrene (The Wealth of India, 1991). Traditionally, the leaves are used to treat liver disease, pain from piles, urinary infections and fever (Kritikar and Basu, 1933). The roots are use as purgative, aperient, diuretic and tonic and also show many therapeutic benefits such as visceral obstructions, jaundice, headaches, urinary diseases and dropsical affections (Suresh et al., 2015). Thereafter, methanolic leaves extract of PI 
have been reported as antipyretic and anti-inflammatory (Mandal et al., 2003). The hepatoprotective activity of the ethanolic extract of PI leaves was investigated against acute and chronic liver damage induced by paracetamol in albino rats (Valte et al., 2018). Antiinflammatory activity of methanolic leaves extract of PI was investigated against carrageenan, histamine and dextran as different inflammatory models in male albino Wistar rats (Mandal et al., 2003). The Anticancer activities of ethanolic extract of PI showed that the higher concentration had a higher inhibition activity against cancer cells (Suresh et al., 2015). The antihelmintic activity of chloroform, petroleum ether, and methanol extracts of PI roots and leaves was investigated against adult Indian earthworms (Pheretima posthuma) and roundworms (Ascaridia gali) (Prasad and Chaurasiya, 2016). Methanol leaves extract of PI also showed diuretic activity (Ramamoorthy et al., 2010). The leaves of PI showed bactericidal activity on Gram-positive bacteria and also inhibited the growth of Gram-negative bacteria (Sujatha and Prakash, 2013). Thereafter, the antidiabetic activity of methanolic extract of $\mathrm{PI}$ and its derived $\mathrm{CHCl}_{3},-\mathrm{BuOH}$, and $\mathrm{H}_{2} \mathrm{O}$ fractions was revealed using its alpha-glucosidase inhibitory potential against the standard drug acarbose using in vitro enzyme assay (Penumala et al., 2017). The antidiabetic potential of methanolic extract of PI was revealed in alloxan induced diabetic rats (Natarajan et al., 2013). Still the scanty reports on antidiabetic activity of this PI plant using streptozotocin induced diabetic mice. Hence, the present investigation was carried out to re-establish the antidiabetic activity of the PI leaves extract with longer duration, i.e., 28 days of study.

\section{Materials and Methods}

\subsection{Collection and authentication of plant material}

The leaves of Pavetta indica L. were collected from the Kolli hills, Namakkal and it was authenticated by Dr. C. Murugan (Scientist and Head) Botanical Survey of India, Coimbatore. The specimen was preserved as herbarium (PI-203/PCOG-2019-20) in the Department of Pharmacognosy, Annai JKK Sampoorani Ammal College of Pharmacy, Komarapalaym, Namakkal.

\subsection{Drugs and chemicals}

Streptozotocin (STZ) (LOBA Chemie, Mumbai, India) was purchased, preserved at $25^{\circ} \mathrm{C}$ and used for this study. Glibenclamide is an oral antidiabetic preparation with an efficient hypoglycaemic action. Diaonil (Glibenclamide) manufactured by Aventis Pharma Ltd. Goa, India, was collected from market and preserved at room temperature. All other chemicals and reagents were used of AR (analytical reagent) grade.

\subsection{Preparation of plant extract}

The fresh leaves of PI were washed thoroughly with tap water and then in distilled water. The washed leaves were shade dried for 21 days until complete dryness and then powdered by the electronic mixer grinder to get coarse powder. About $500 \mathrm{~g}$ of dry powder was extracted with methanol solvent by using Soxhlet apparatus for $7 \mathrm{~h}$ at $40^{\circ} \mathrm{C}$. After completion of solvent extract, it was filtered with Whatman filter paper and further concentrated to a dry viscous mass by using rotary flash evaporator at $35^{\circ} \mathrm{C}$.

\subsection{Calculation of yield and phytochemical screening}

The extract was subjected to calculate the yield followed by phytochemical analysis to test the presence of the group of phytoconstituents present in leave extracts through various specific chemical tests as per the method described by the standard literature (Khandelwal, 2007).

\subsection{Animals}

Swiss albino mice of Sprague - Dawley strain (20-25 g) of either sex $(n=36)$ were procured from animal house of our Institute and used for the present investigation. The animals were fed a standard pellet diet and water ad libitum. They were maintained in a controlled environment and temperature $\left(22 \pm 5^{\circ} \mathrm{C}\right.$ with $12 \mathrm{~h}$ of light/dark cycle) as per the standard protocol followed and as per the animal ethical approval given by the Institutional Animal Ethical Committee (12/2009/CPCSEA).

\subsection{Acute toxicity study}

Acute toxicity study of the plant extract of PI was carried out in Swiss albino mice $(n=6)$ according to OECD (Organization for Economic Cooperation and Development) guidelines No. 423. Extract at different doses up to $2000 \mathrm{mg} / \mathrm{kg}$ p.o. was administered and the animals were observed for behavioural changes, toxicity, and mortality up to $48 \mathrm{~h}$ (OECD, 2007).

\subsection{Induction of diabetes}

Hyperglycemia was induced by streptozotocin at a dose of $60 \mathrm{mg} /$ $\mathrm{kg}$ i.p. The animals were kept under observation. After $48 \mathrm{~h}$, the animals were tested for glucosuria using Diastex strips (Eidi et al., 2005). 14 days after the STZ injection, mice with fasting blood glucose levels greater than $200 \mathrm{mg} / \mathrm{dl}$ were considered diabetic condition, were used for the present investigation.

\subsection{Treatment protocol}

Diabetic animals were randomly assigned into the five groups of six animals each and treated as follows:

Table 1: Phytochemical analysis of $P$. Indica leaves extract

\begin{tabular}{|c|ll|}
\hline Sl.No. & \multicolumn{1}{|c|}{ Groups } & \multicolumn{1}{c|}{ Treatments } \\
\hline I & Normal (Non diabetic) & Normal distilled water \\
II & Diabetic control & STZ induced $(60 \mathrm{mg} / \mathrm{kg})$ i.p. \\
III & Standard & $\begin{array}{l}\text { STZ induced diabetic } \\
\text { mice }+ \text { glibenclamide } \\
(10 \mathrm{mg} / \mathrm{kg} \text { b.w.) }\end{array}$ \\
& & $200 \mathrm{mg} / \mathrm{kg}$ \\
IV & Induced diabetic mice \\
& + PI methanol extract & \\
V & Induced diabetic mice & $400 \mathrm{mg} / \mathrm{kg}$ \\
& + PI methanol extract & \\
\hline
\end{tabular}

2.9 Effect on oral glucose tolerance test in STZ-induced diabetic mice

All the above grouped animals except Group-II were given glucose $(2 \mathrm{~g} / \mathrm{kg}) 30 \mathrm{~min}$ after dosing. Blood samples were collected from the mice tail vein just before glucose administration $(0 \mathrm{~h})$ and 30, 60, and $90 \mathrm{~min}$. After the glucose loading, blood glucose levels were estimated by using glucometer (Kalarani et al., 2012).

\subsection{Body weight determination}

The body weight of all groups of mice were calculated and documented before treatment (day 0 ) and after the experimental 
period (on days 7, 14, 21 and 28) through electronic weighing balance.

\subsection{Estimation of blood glucose level}

Blood samples were collected at weekly intervals up to the end of the study, i.e., 28 days. Blood glucose was estimated by electronic glucometer using blood glucose strips. On day 28, blood was collected from the mice tail vein (overnight fasted mice) and blood sugar was estimated. Separated serum was analyzed for serum cholesterol and serum triglycerides by enzymatic DHBS colorimetric method, and serum high-density lipoprotein (HDL), serum lowdensity lipoprotein (LDL), serum creatinine, and serum urea were examined. Furthermore, the activities of alkaline phosphatase (ALP), aspartate, and alanine transaminases (AST and ALT) were also estimated using Randox Assay kits (Singh et al., 2018).

\subsection{Statistical study}

All the values of body weight, fasting blood glucose level, and biochemical parameter estimations were expressed as mean \pm SEM and was analyzed for significance by one-way ANOVA followed by Dunnette's multiple comparison test using In Stat v.2.02 software
(GraphPad Software Inc.). Differences between groups (p Value) were considered significant at $p<0.05$ level.

\section{Results}

\subsection{Yield and phytochemical investigation}

In the present study, methanol solvent was used for the crude extract preparation for the leaves of PI. The crude extract from the dried leaves of PI showed the yield of $28.27 \%$ w/w. Thereafter, various chemical tests were performed and revealed the presence of alkaloids, carbohydrate, flavonoids, phenolic and tannins as major bioactive constituents.

\subsection{Acute toxicity study}

During acute toxicity study, it was observed that the MEPI was safe to use in animals and showed no mortality at the dose level of $2000 \mathrm{mg} / \mathrm{kg}$ b.w. Therefore, $2000 \mathrm{mg} / \mathrm{kg}$ dose was considered as a safe dose and further, $1 / 5$ th $(400 \mathrm{mg} / \mathrm{kg}$ b.w.) and 1/10th $(200 \mathrm{mg} /$ $\mathrm{kg}$ b.w.) dose were selected for carried out the whole experiment and also indicated that $\mathrm{LD}_{50}$ for MEPI could be greater than $2 \mathrm{~g} / \mathrm{kg}$ b.w in mice.

Table 2: Effect on glucose tolerance of MEPI on streptozotocin induced diabetic mice

\begin{tabular}{|c|l|c|c|c|c|}
\hline \multirow{2}{*}{ Groups } & \multirow{2}{*}{ Treatment } & \multicolumn{4}{|c|}{ Change in blood glucose levels (mg/dl) } \\
\cline { 3 - 6 } & & $\mathbf{0}^{\text {th }}$ min & At 30 min & At 60 min & At 90 min \\
\hline I & Normal control(Vehicle only) & $62.92 \pm 2.10$ & $152.10 \pm 2.76$ & $160.80 \pm 2.90$ & $154.90 \pm 3.10$ \\
II & Glibenclamide $10 \mathrm{mg} / \mathrm{kg}$ & $70.69 \pm 2.08$ & $101.17 \pm 2.38^{\mathrm{a}}$ & $119.60 \pm 3.20^{\mathrm{a}}$ & $86.18 \pm 3.10^{\mathrm{a}}$ \\
III & MEPI $200 \mathrm{mg} / \mathrm{kg}$ & $68.76 \pm 1.5$ & $130.08 \pm 3.87^{\mathrm{b}}$ & $146.52 \pm 3.26^{\mathrm{c}}$ & $98.76 \pm 3.18^{\mathrm{c}}$ \\
IV & MEPI400 $\mathrm{mg} / \mathrm{kg}$ & $66.42 \pm 2.12^{\mathrm{a}}$ & $107.88 \pm 4.90^{\mathrm{a}}$ & $123.26 \pm 2.23^{\mathrm{a}}$ & $91.88 \pm 2.91^{\mathrm{a}}$ \\
\hline
\end{tabular}

All values are expressed as mean \pm SEM $(\mathrm{n}=6)$, statistically significant at ${ }^{\mathrm{a} *}=p<0.001^{\mathrm{b}}=p<0.01 ;{ }^{\mathrm{c}}=p<0.05$. Values are compared with normal by using one-way ANOVA followed by Dunnette's multiple comparison test.

\subsection{Effect on oral glucose tolerance test}

The effects of MEPI on the OGTT in normal mice were estimated. After 30 min of glucose administration, a rapid increase in blood glucose occurred in the fasting animals and then decreased subsequently during the time intervals. The standard glibenclamide administered group $(10 \mathrm{mg} / \mathrm{kg})$ had drastically reduced hyperglycemia at 30,60 and $90 \mathrm{~min}(101.17,119.60$, and $86.18 \mathrm{mg} /$ $\mathrm{dl}$, respectively) as compared to the normal control group at the same time intervals. Maximum glucose tolerance in MEPI was observed as 98.76 and the minimum was observed as 91.88 in 90 min as compared with Group I (Table 1).

\subsection{Changes in body weight}

At the end of 28 days treatment, the body weight of normal rats, MEPI and standard drug treated group increased significantly; whereas body weight of diabetic control group decreased (Figure 1). The study was showed in 28 days, MEPI at dose levels of 200 and $400 \mathrm{mg} / \mathrm{kg}$ resulted significantly increased in body weight from $25 \mathrm{~g}$ to $32 \mathrm{~g}$ and diabetic control group was resulted decrease in body weight from $25 \mathrm{~g}$ to $16 \mathrm{~g}$ as compared to normal mice weight (increased body weight from $25 \mathrm{~g}$ to $60 \mathrm{~g}$ in 28 days). MEPI treated groups were also compared with diabetic control group.

\subsection{Estimation of lipid profile}

The animals treated with MEPI showed significant reductions $(p<0.01)$ in lipid profile parameters, viz., 84.41 and $80.11 \mathrm{mg} / \mathrm{dl}$ cholesterol, 45.33 and $34.24 \mathrm{mg} / \mathrm{dl} \mathrm{LDL}, 16.85$ and $18.22 \mathrm{mg} / \mathrm{dl}$ VLDL and 86.43 and $74.29 \mathrm{mg} / \mathrm{dl}$ triglycerides after treatment with MEPI (250 and $500 \mathrm{mg} / \mathrm{kg}$ ), respectively when compared with diabetic control mice. Furthermore, a decrease level of HDL observed with the diabetic control group when compared with the normal group but increased with standard drug as well as with MEPI extracts significantly $(p<0.05)$ with the dose dependant manner (Table 2$)$.

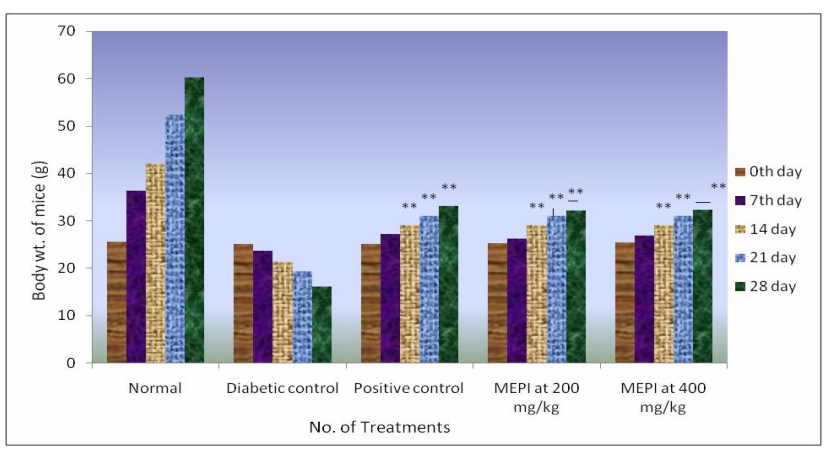

Figure 1:Effect of MEPI on body weight in STZ-induced diabetic mice.

$* p<0.05, * * p<0.01$, values are mean \pm SEM, $\mathrm{n}=6$, when compared with normal and diabetic control by using one-way ANOVA followed by Dunnette's multiple comparison test 
Table 3: Effect of MEPI on serum lipid profile after 28 days

\begin{tabular}{|c|cc|c|cc|}
\hline Group & Cholesterol $(\mathbf{m g} / \mathbf{d l})$ & LDL $(\mathbf{m g} / \mathbf{d l})$ & HDL $(\mathbf{m g} / \mathbf{d l})$ & VLDL $(\mathrm{mg} / \mathbf{d l})$ & Triglycerides \\
\hline I & $68.12 \pm 0.05$ & $20.64 \pm 0.12$ & $12.03 \pm 0.04$ & $16.20 \pm 0.04$ & $60.21 \pm 0.21$ \\
II & $87.33 \pm 0.11$ & $96.43 \pm 0.33$ & $9.10 \pm 0.24$ & $20.34 \pm 0.03$ & $117.03 \pm 0.10$ \\
III & $73.22 \pm 0.23^{* *}$ & $38.56 \pm 0.20^{* *}$ & $14.43 \pm 0.21^{* *}$ & $17.98 \pm 0.43^{* *} 73.21 \pm 0.14^{* *}$ \\
IV & $84.41 \pm 0.31^{* *}$ & $45.33 \pm 0.21^{* *}$ & $16.21 \pm 0.42^{* *}$ & $16.85 \pm 0.03^{* *}$ & $86.43 \pm 0.44^{* *}$ \\
V & $80.11 \pm 0.11^{* *}$ & $34.24 \pm 0.10^{* *}$ & $20.76 \pm 0.12^{* *}$ & $18.22 \pm 0.10^{* *} 74.29 \pm 0.20^{* *}$ \\
\hline
\end{tabular}

${ }^{*} p<0.05, *^{*} p<0.01$, values are mean $\pm \mathrm{SEM}, \mathrm{n}=6$, when compared with diabetic control by using one-way ANOVA followed by Dunnette's multiple comparison test.

\subsection{Blood glucose level estimation}

Blood glucose was estimated at $0,7,14,21$, and 28 days for all the treated groups of mice. The glibenclamide and MEPI treated groups $(200,400 \mathrm{mg} / \mathrm{kg} \mathrm{b} . \mathrm{w})$, showed a significant reduction $(p<0.05)$ from 7 th to $28^{\text {th }}$ day. STZ induced MEPI at dose level of $400 \mathrm{mg} / \mathrm{kg} \mathrm{b.w}$ showed a significant reduction in blood glucose level $(p<0.05)$ (Figure 2). Animals with STZ induced diabetes $60 \mathrm{mg} / \mathrm{kg}$ b.w. (i.p) had elevated blood glucose on first day and after 28 days, it was reduced a little but was higher than that of normal group.

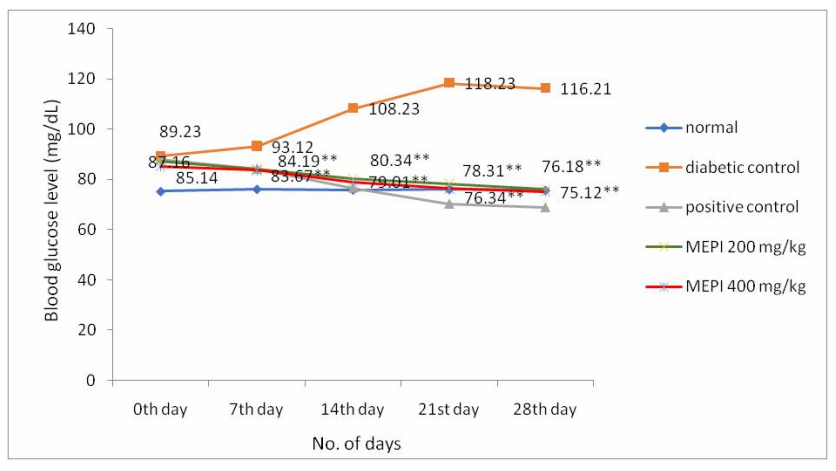

Figure 2: Effect of MEPI on blood glucose level in STZ-induced diabetic mice.

$*_{p}<0.05, * * p<0.01$, values are mean \pm SEM, $\mathrm{n}=6$, when compared with diabetic control by using one-way ANOVA followed by Dunnette's multiple comparison test

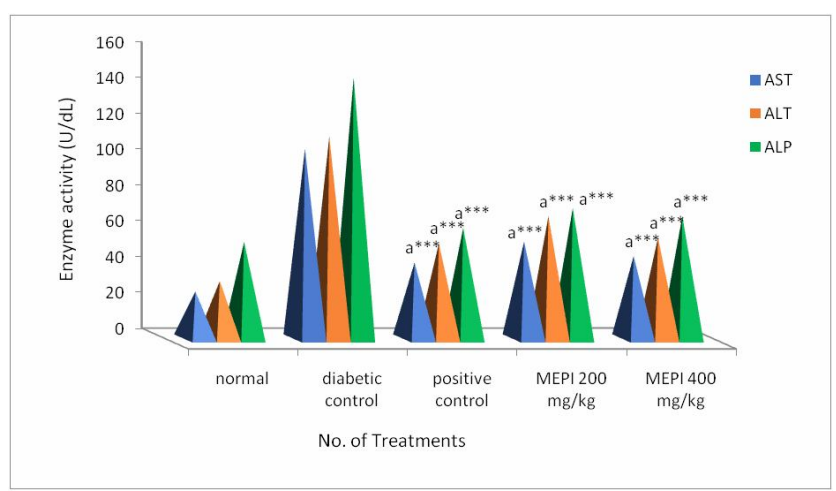

Figure 3: Effect of MEPI on enzyme activity in STZ-induced diabetic mice.

Values are mean $\pm \mathrm{SEM}, \mathrm{n}=6$; ${ }^{\mathrm{a}} p<0.05$, when compared with normal control $* * * p<0.001$, when compared with diabetic control by using one-way ANOVA followed by Dunnette's multiple comparison test.

\subsection{Serum enzyme level}

Activities of serum enzymes such as ALP, AST and ALT were determined. The activity of enzymes is increased much higher with STZ induced mice than normal, which gave significant $(p<0.05)$ results in 28 days. Furthermore, diabetic animals treated with the standard drug showed a significant decrease in enzyme activity. MEPI at 200 and $400 \mathrm{mg} / \mathrm{kg}$ b.w resulted significant decrease in enzyme activity at dose dependent manner but the values are close with the standard group mice (Figure 3). Data revealed that MEPI at dose of $400 \mathrm{mg} / \mathrm{kg}$ b.w showed the values of AST- $46.12 \mathrm{U} / \mathrm{dl}$; ALT-56.34 U/dl; ALP-68.43 U/dl which were close to the STZ induced glibenclamide group of animals (AST-42.43 U/dl; ALT-53.23 U/dl and ALP-61.80 U/dl) but the values were significant when compared with positive control group $(p<0.001)$ and normal group of animals $(p<0.05)$.

\section{Discussion}

DM is a chronic condition and being considered a public health problem in terms of population growth and ageing, greater urbanization, the increasing prevalence of obesity (Whiting et al., 2011). In the present study, phytochemical evaluation with respect to chemical tests is required to identify preliminary phytoconstituents present in herbal extracts. Plant active constituents are essential for therapeutic efficacy. Hence, the chemical test for MEPI was carried out for the identification of the presence of group of constituents. Mechanisms of action of phytoconstituents involve regulating glycemic metabolism or decreasing cholesterol levels or increasing secretion of insulin or by improving microcirculation (Das et al., 2020). The present investigation was carried out for qualitative identification of the phytoconstituents present in the MEPI. Methanol extract was selected because most of the important phytoconstituents related to antidiabetic activity are soluble. Further, the methanolic leaves extract of PI $(200$ and $400 \mathrm{mg} / \mathrm{kg}$ body weight) was investigated for antidiabetic activity on STZ diabetic mice and resulted significant declines of body weight gain in STZ-diabetic mice were noted after 28 days. Similar observations were noted in many experimental diabetes researches (Jayaprasad et al., 2015; Jayaprasad et al., 2016; Das et al., 2020).

Increased food consumption and decreased body weight observed in diabetic mice in comparison to normal mice, indicates a polyphagic condition and weight loss due to excessive breakdown of tissue proteins (Chatterjea and Shinde, 2002). In the present study, the levels of blood glucose, total protein, cholesterol, LDL and VLDL were significantly higher, while the level of HDL was statistically decreased in diabetic mice. All the observations were similar with the previous scientific investigations (Achi et al., 
2016; Hu et al., 2016; Zhang et al., 2016). This may be due to the presence of polyphenolic compounds, especially flavonoids in the leaves, which are incorporated into lipoprotein within the liver or intestine and transported within the lipoprotein particles which are inversely associated with mortality from coronary heart disease. Therefore, flavonoids and phenolics may be located for protection of LDL from oxidation. The same result was revealed earlier (Safdar et al., 2003). Furthermore, flavonoids are reported to suppress glucose level and also found to be a strong inhibitor of $\alpha$-glucosidase (Kim et al., 2000). MEPI leaf extract also showed the presence of phenolics in higher content and that is the reason for the decrease in blood glucose level.

In the further investigation, there was a significant rise in the serum enzyme levels such as AST, ALT, and ALP. Results revealed the increased level of all the enzymes in the diabetic control group compared to the normal control group, and thereafter the standard drug decreased the values, the activity was may be due to the cell membrane damage of hepatocytes or due to increased cell membrane permeability (Nwufo et al., 2017). The activities of ALT, AST, and ALP in serum are increased due to the leakage of these enzymes (in the liver cytosol) and as a result diabetes may induce hepatic dysfunction.

\section{Conclusion}

In the present study, the leaves methanolic extract of $P$. indica was investigated for antidiabetic activity by STZ induced diabetic mice for the duration of 28 days. The study showed the presence of various plant constituents and among the all, flavonoids are the one that are possibly responsible for the antidiabetic activities may be by triggers insulin secretion, and demonstrated significant lowering of blood glucose level, and biochemical parameters. Further, statistical improvement in the body weight of animals showed in a dose-dependent manner by enhanced peripheral glucose utilization by direct stimulation of glucose uptake and reduced blood glucose level.

\section{Acknowledgements}

Authors are thankful to JKKMMRF'S - Annai JKKS Ampoorani Ammal College of Pharmacy B. Komarapalayam, Tamil Nadu, India for providing all the facilities and support to carry out the present experiment.

\section{Conflict of interest}

The authors declare no conflicts of interest relevant to this article.

\section{References}

Achi, N.K.; Ohaeri, O.C.; Ijeh, I.I. and Eleazu, C. (2016). Modulation of the lipid profile and insulin levels of streptozotocin induced diabetic rats by ethanol extract of Cnidoscolus aconitifolius leaves and some fractions: Effect on the oral glucose tolerance of normoglycemic rats. Biomed. Pharmacother., 86:562-569.

Das, K.; Saifulla Khan, M.; Sounder, J.; Mohan, U. and Venkatesh Prasad, S. (2020). Phytochemical screening and establishment of the antidiabetic potential of aqueous leaf extract of the rndangered plant Decalepis nervosa in rats with alloxan-induced diabetes. Turk. J. Pharm. Sci., 17(3):319-328.
Dubey, P.; Jayant, S.K. and Srivastava, N. (2020). Preliminary phytochemical screening, FTIR and GC-MS analyses of aqueous, ethanolic and methanolic extracts of stem of Tinospora cordifolia (Guduchi) for search of antidiabetic compounds. Ann. Phytomed., 9(2):183-197.

Eidi, M.; Eidi, A. and Zamanizadeh, H. (2005). Effect of Salvia officinalis L. leaves on serum glucose and insulin in healthy and streptozotocininduced diabetic rats. J. Ethnopharmacol., 100(3):310-313.

Gupta, V.K.; Kaur, C.; Simlai, A. and Roy, A. (2013). Antimicrobial activity of Pavetta indica leaves. Journal of Applied Pharmaceutical Science, 3(4):78-82.

Hu, X.; Cheng, D. and Zhang, Z. (2016). Antidiabetic activity of Helicteres angustifolia root. Pharm. Biol., 54:938-944.

IDF Diabetes Atlas. (2013). 6th Ed. Belgium: International Diabetes Federation.

Jayaprasad, B.; Sharavanan, P.S. and Sivaraj, R. (2015). Effect of Chloroxylon swietenia Dc bark extracts on STZ induced diabetic rats with special attention to its glycoprotein levels. Der. Pharmacia Lett., 7:414418 .

Jayaprasad, B.; Sharavanan, P.S. and Sivaraj, R. (2016). Antidiabetic effect of Chloroxylon swietenia bark extracts on streptozotocin induced diabetic rats. Beni-Suef Univ. J. Basic Appl. Sci., 5:61-69.

Kalarani, D.H.; Dinakar, A. and Senthilkumar, N. (2012). Antidiabetic activity of ethanolic extracts of Alangium salvifolium and Pavonia zeylanica in streptozotocin induced diabetic rats. Int. J. Pharm. Pharmaceuti. Sci., 4:337-339.

Khandelwal, K.R. (2007). Practical Pharmacognosy, Nirali publication, Pune, India, 18 th edition.

Kim, J.S.; Kwon, C.S. and Son, K.H.(2000). Inhibition of alpha-glucosidase and amylase by luteolin, a flavonoid. Biosci. Biotechnol. Biochem., 64:2458-2461.

Kritikar, K.R. and Basu, B.D. (1933). Indian Medicinal Plants. Vol. 3, L.M. Basu, Allahabad, India, pp:17-89.

Lanjhiyana, S.; Garabadu, D.; Ahirwar, D.; Bigoniya, P.; Rana, A. C.; Patra K. C.; Lanjhiyana, S.K. and Karuppaih, M. (2011). Hypoglycemic activity studies on root extracts of Murraya koenigii root in alloxaninduced diabetic rats. J. Nat. Prod. Plant Resour., 1(2):91-104.

Mandal, S.C.; Lakshmi, S.M. Kumar, C.K.A. Sur, T.K. and Boominathan, R. (2003). Evaluation of anti-inflammatory potential of Pavetta indica Linn. leaf extract (Family: Rubiaceae) in rats. Phytother. Res., 17:817-820.

Manickam, D. and Periyasamy, L. (2013). Antidiabetic effect of methanolic extract of Decalepis hamiltonii root in normal and alloxan induced diabetic rats. Journal of Pharmacy Research, 16(6):166-172.

Natarajan, P.; Thangathirupathi, A.; Ramarajan, S.; Jaya, S. and Bellamkonda Hareesh, G.L. (2013). Preliminary study of antidiabetic activity of methanolic extract of Pavetta indica Linn in diabetic rats. Asian J. Pharm. Clin. Res., 6(1):131-133.

Nwufo, C.; Ene, A.C.; Emejulu, A.A.; Obasi, U.K. and Ene, C.U. (2017). Antidiabetic properties of ethanolic root extract of Mucuna pruriens on alloxan induced diabetic rats. Int. J. Res. Pharm Biosciences, 4:17-29.

Nyunai, A. B. N.; Njikama, N.; Abdennebic, E. L. H.; Tanyi Mbaford, J. and Lamnaouerc, D. (2009). Hypoglycemic and antihyperglycaemic activity of Ageratum conyzoidesin rats. Afr. J. Trad. CAM., 6(2):123-130.

Organization for economic co-operation and development. OECD Guidelines. (2007). Guidance document on acute oral toxicity testing (2001) series on testing and assessment no. 24; Paris: OECD environment, health and safety publications.

Patil, A. A.; Koli, A. S.; Darshana, A.; Patil, B.; Narayane, C. V. and Phatak, V. A. A. (2013). Evaluation of effect of aqueous slurry of Curculigo orchioides Aertn. rhizome in streptozotocin induced diabetic rats. Journal of Pharmacy Research, 7:747-753. 
Penumala, M.; Zinka, R.B.; Shaik, J.B. and Amooru Gangaiah, D. (2017). In vitro screening of three Indian medicinal plants for their phytochemicals, anticholinesterase, antiglucosidase, antioxidant, and neuroprotective effects. BioMed. Research International, pp:5140506. doi: $10.1155 / 2017 / 5140506$

Prasad, S. and Chaurasiya, A. (2016). In vitro evaluation of anthelmintic activity of the roots and leaves of Pavetta indica Linn. International Journal of Pharmacy and Life Sciences, 7(6):5094-5098.

Ramamoorthy, J.; Venkataraman, S.; Meera, R.; Chiristina, A.J.; Chidambar anathan, N.; Devi, P. and Prasad, S. (2010). Physiophytochemical screening and diuretic activity of leaves of Pavetta indica Linn. Journal of Pharmaceutical Sciences and Research, 2(8):506-512.

Safdar, M.; Khan, A.; Khan Khattak, M.M.A. and Siddique, M. (2003). Effect of various doses of cinnamon on blood glucose in diabetic individuals. Pak. J. Nutri., 2:313-319.

Seshiah, V. (2016). Classification and diagnosis of diabetes mellitus. A handbook on diabetes mellitus, $7^{\text {th }}$ New Delhi and Chennai: All India publishers and distributors. 16.

Singh, A.; Srivastav, R. and Pandey, A.K. (2018). Effect of the seeds of Terminalia chebula on blood serum, lipid profile and urine parameters in STZ induced Diabetic rats. J. Pharmacog. Phytochem., 7:1-5.
Sujatha, S and Prakash, G. (2013). Bioactive screening and antimicrobial activity of flowers from the selected three medicinal plants on chosen microbes. Int. J. Curr. Microbiol. Appl. Sci., 2(5):211221 .

Suresh, S.; Pradheesh, G. and Ramani, V.A. (2015). Phytochemical screening and GC-MS studies of the medicinal plant Pavetta indica Linn. American Journal of Ethnomedicine, 2(6):347-355.

The Wealth of India. (1991). A dictionary of Indian raw materials and industrials products. Raw Materials, 7:282.

Valte, V.; Singh, M.P.; Raleng, I. and Losica, R.K. (2018). Hepatoprotective activity of ethanol extract of Pavetta indica Linn leaves. International Journal of Basic and Clinical Pharmacology, 7(5): 1006-1010.

Whiting, R.D.; Guariguata, L.; Weil, C. and Shaw, J. (2011). IDF diabetes stlas: global estimates of the prevalence of diabetes for 2011 and 2030. Diabetes Res. Clin. Pract., 94 : 311-321.

Zhang, Y.; Feng, F.; Chen, T.; Li, Z. and Shen, Q.W. (2016). Antidiabetic and antihyperlipidemic activities of Forsythia suspensa (Thunb.) Vahl (fruit) in streptozotocin-induced diabetes mice. J. Ethnopharmacol., 192:256-263. 